City University of New York (CUNY) CUNY Academic Works

\title{
Latino students and the academic library: a primer for action
}

Marta Bladek

CUNY John Jay College

\section{How does access to this work benefit you? Let us know!}

More information about this work at: https://academicworks.cuny.edu/jj_pubs/254

Discover additional works at: https://academicworks.cuny.edu

This work is made publicly available by the City University of New York (CUNY).

Contact: AcademicWorks@cuny.edu 


\title{
Latino students and the academic library: A primer for action
}

\begin{abstract}
As the growth in Latino college enrollment is expected to continue for years to come, academic libraries at Hispanic Serving Institutions (HSIs) and beyond will be serving increasing numbers of Hispanic students. Since Latino educational attainment remains lower than than of other groups and academic libraries' impact on retention, GPA and related educational outcomes has been well documented, it is crucial that academic libraries actively foster Latino students' success. A review of the literature on Hispanic students and library use, the article also includes recommendations for practice and offers a local example to illustrate strategies libraries may implement to better meet the educational needs of Hispanic students.
\end{abstract}

Keywords: academic libraries, Latino students, library services, reference services, instruction, Hispanic Serving Institutions (HSIs), literature review

\section{Introduction}

This article is intended as a primer for academic libraries that serve large or increasing numbers of Latino students. An overview of demographic trends and their impact on higher education is followed by a review of the literature on Hispanic students and academic libraries. In addition to focusing on how Latino students perceive and use libraries, the article surveys the literature on Latino students and information literacy, including examples of successful librarian-faculty collaborations. The article also lists recommendations for practice that emerge from the literature. Finally, to illustrate strategies libraries may implement to better meet the educational needs of Hispanic students, it offers the example of the Lloyd Sealy Library at John Jay College of Criminal Justice, CUNY. 


\section{Higher Education and Latinos}

\section{Latinos in the United States: Demographic Trends}

In 2015, 56.5 million Latinos, of whom 37.1 million were U.S.-born, accounted for $17.6 \%$ of the total U.S. population, marking a ninefold increase since 1960 when they accounted for 6.3 millions of US residents (Flores, Lopez, \& Radford, 2017). ${ }^{1}$ Current projections estimate that the growth will continue; it is expected that by 2065 there will be 107 million Latinos in the United States, adding up to $24 \%$ of the total population (Flores, 2017). At $63.3 \%$ of the total Latino population, Mexican Americans are the largest group, with Puerto Ricans (9.5\%), Salvadorans (3.8\%) and Cubans (3.7\%) constituting the next three largest groups (Flores, 2017). Importantly, with the median age of 28 , Latinos are the youngest racial or ethnic group (Patten, 2016). See Table 1 for a breakdown of generational cohorts and race and ethnicity. In 2014 , those 18 or younger accounted for about one-third, or 17.9 million, of the overall Latino population, and $50 \%$ of the U.S. born; those between the ages of 18 and 33 added up to 14.6 million, or about $25 \%$ of all Latinos (Patten, 2016). The younger cohorts of Latinos have a higher English proficiency than older generations. See Table 2 for details. $88 \%$ of Latinos between the ages 5 to 17 are proficient English speakers, and 37\% of them speak only English at home (Patten, 2016). Among those aged 18 to 33, English proficiency rate is $76 \%$, with $28 \%$ speaking English only at home (Patten, 2016).

\footnotetext{
${ }^{1}$ The U.S. Census uses the terms "Hispanic or Latino" to refer to persons "of Cuban, Mexican, Puerto Rican, South or Central American, or other Spanish culture or origin regardless of race" (Humes, K., Jones, N.A., \& Ramirez, R. R., 2011). Following the official government definition, the paper also uses the term Hispanic and Latino interchangeably.
} 
The above demographic trends have carried over to the educational system, including postsecondary institutions. Colleges and universities have seen a marked growth in Hispanic enrollment in recent decades. In the fall of 1976, Hispanics accounted for just 4 percent of college students; by fall 2015 they accounted for 17 percent of the total student body (National Center for Education Statistics, n.d.). It is estimated that by 2020, Latinos will make up nearly 25\% of college-aged adults (Molteni, V. E., \& Bosch, 2014, p. 52-52).

Although Latino educational attainment has been steadily rising over the decades, currently $11 \%$ of Latinos 25 years old or older hold a bachelor's degree compared to $19.7 \%$ of the total U.S. population in the same age group (Flores, Lopez, \& Radford, 2017; United States Census Bureau, 2017). The Latino college attrition is higher than the overall rate. In the 2009 cohort at four year institutions, the six-year graduation rate for Latinos was $53.6 \%$ as compared to the total rate of $59.6 \%$, and $63.3 \%$ and 72.3\% for whites and Asians respectively (National Center for Education Statistics, 2016).

\section{Hispanic Serving Institutions (HSIs)}

Since the 1980s, there has been a recognition of the unique issues faced by institutions enrolling large numbers of Hispanic students (Santiago and Andrade, 2010). In light of documented educational disparities between Hispanics and other communities, President George H. W. Bush established the White House Initiative on Educational Excellence for Hispanics in 1990; all subsequent administrations have continued to support its goals of promoting Hispanic success starting with early childhood education through college (U.S. Department of Education, n.d., White House ...). In 1992, over a decade after the urgent need to support institutions with growing Latino enrollments was first articulated, Hispanic Serving 
Institutions (HSIs) were formally defined in the amended Higher Education Act of 1965 (Excelencia in Education, 2014). The official definition of HSIs specifies that HSIs are non-profit colleges and universities whose full-time equivalent (FTE) student enrollment has reached at least 25 percent Latino (U.S. Department of Education, 2016). HSIs qualify for specifically designated federal funding, including Title III and Title V grants, that supports the development, improvement, and expansion of "the academic offerings, program quality, and institutional stability of the colleges and universities that educate the majority of Hispanic students" (U.S. Department of Education, n.d., Hispanic Serving Institutions). The most recent list of HSIs, compiled by the Hispanic Association of Colleges and Universities (HACU) for the 2016-2017 academic year, features a total of 492 private and public colleges and universities, 237 of which are two-year institutions, as well as 333 emerging HSIs (with Latino FTE between 15 and 24 percent), 111 of which are two-year colleges (Hispanic Association of Colleges \& Universities, n.d.).

As Santiago and Andrade (2010) note, "the theory that institutions enrolling a large concentration of Latino students would adapt their institutional practices to serve these students better" was the driving factor behind the official designation of HSIs (3). In the context of colleges and universities with growing numbers of Latino students, the critical mass theory Santiago and Andrade invoke (2010) posits that these institutions will necessarily have to reformulate their "culture, discourse, and agenda" (p. 7) in order to meet the needs of their communities. Accordingly, as it works towards greater Latino student success, an HSI will need to revise curricular design and offerings, modify teaching methods, reevaluate academic program offerings, and expand the range of support services (Santiago \& Andrade, 2010). 


\section{Academic Libraries and Student Success}

There is a growing body of literature documenting the most effective practices for serving Latino students well. Although Latinos enter college less academically prepared than other groups and experience additional life challenges, including language proficiency and financial stress issues, certain college services, programs, experiences, and conditions modulate against these disadvantages (Molteni and Bosch 2014; Montiel-Overall, Nuñez, \& Reyes-Escudero, 2015; Nora 2009). The following paragraph offers an overview of recurring themes in the HSI literature that are especially relevant to and potentially adaptable by libraries at HSIs and beyond.

Social and academic integration have been shown to positively impact Latino students' persistence and related educational outcomes (Kiyama, Museus, \& Vega (2015); Maestas, Vaquera, \& Zehr, 2007; Nora \& Crisp, 2009; Nuñez, 2013). Consisting of a wide range of campus, classroom, co-curricular and social experiences that collectively foster a sense of belonging to the community, social integration also includes the formation of relationships with faculty and staff. Meaningful and caring interactions with faculty positively correlate with higher grades and retention, as well other measures of student success (Kiyama, Museus, \& Vega, 2015; Maestas, Vaquera, \& Zehr, 2007). The perception of institutional diversity, the presence of role models and mentors among faculty and staff, and an overall culturally validating campus environment all contribute to making Latino students feel at home and more likely to continue their education (Kiyama, Museus, \& Vega, 2015; Nora \& Crisp, 2009). Academic integration, in turn, refers to the varied ways in which colleges and universities support and provide resources that allow students to reach their educational goals. The ability 
to get assistance at point of need (tutoring, writing center, computer workstations), the availability and variety of academic support programs, faculty involvement, and campus conditions and facilities that promote study habits all contribute to higher Latino achievement (Maestas, Vaquera and Zehr (2007)). All in all, as Kiyama, Museus, \& Vega (2015) sum up the features of HSI campus environments optimally equipped to address and serve Latino students' particular needs, they need to "reflect the conditions that are necessary for Latinos/as to thrive in college" (p. 34).

Academic libraries at HSIs and beyond have started to recognize the need to assess and meet the needs of Latino students. Given their documented impact on retention, GPA and related educational outcomes, it is imperative that academic libraries be actively engaged in fostering Latino students' success. In order to better serve the growing numbers of Hispanic students, libraries should be ready to adapt their services, resources and even spaces. Below is brief summary of the evidence for libraries' various contributions to student learning, followed by an overview of the expanding body of LIS literature on Latinos and academic libraries, including a list of selected best practices.

A growing body of research presents evidence of the various ways in which academic libraries support students' learning, generally captured through measures such as course grades, cumulative grade point average (GPA), term retention, and degree attainment. Collected in the past decade, the findings consistently illustrate the crucial role public and private college libraries, both small and large, play in students' academic lives. Importantly, a number of researchers have documented these positive relationships while controlling for students' demographic characteristics, including gender, socioeconomic, first generation and 
Pell Grant recipient status, high school GPA, and concurrent college experiences (LeMaistre, Shi, \& Thanki 2018; O’Kelly 2015; Soria, Fransen, \& Nackerud, 2013). In her review of studies documenting libraries' unique contribution to students' academic success throughout their college careers, Oliveira (2017) identifies three key areas: library instruction, library space and the use of library materials. Libraries' programmatic role in campus-wide High Impact Practices (HIPs), including first-year seminars, common intellectual experiences, writing-intensive courses, undergraduate research, diversity and global learning, capstone courses and projects, has also been demonstrated (Murray, 2015).

One of the largest studies focusing on academic libraries is the the Library Impact Data Project conducted at the University of Huddersfield in the UK and its seven partner institutions (Stone, Pattern \& Ramsden 2011; Stone 2015). Preliminary and subsequent analyses have shown that library use, measured by three distinct indicators (the use of online resources, print book borrowing and visits to the library) bears a relationship to how well students do in college. While no definitive relationship was determined between the number of a student's visits to the library and their academic standing, the use of electronic resources and borrowing of materials have been shown to relate positively to their GPA, term retention and degree completion (Stone, Pattern \& Ramsden 2011; Stone 2015). At the University of Nebraska Lincoln, Allison (2015) focused her two-year study on electronic resources usage and book borrowing, the two indicators Stone (2015) has found positively linked with GPA and retention. She found that undergraduate and graduate students with higher-than-average GPA rely on these services more often than other students (Allison, 2015). 
While the Library Impact Data Project (Stone, Pattern, \& Ramsden 2011; Stone 2015) and Allison's (2015) showed how the use of online resources and book borrowing relates to GPA and retention, other researchers examined how additional multiple library service points affect academic attainment across the college career span. Examining first-year student library data usage across a variety of service points at the University of Minnesota Libraries--Twin Cities, Soria, Fransen, \& Nackerud (2013) found that new students who use the library have a higher first-term GPA and higher retention Fall to Spring than non-users. At Indiana University Kokomo, Thorpe, Lukes, Bever, \& He (2016) looked at data at multiple services, including reference consultations (in person, by email, chat, and phone), book borrowing, interlibrary loan requests, library instruction and electronic resources. Overall, for all cohorts, they found that students who use the library more often have higher GPA and are retained at a higher rate than nonusers (Thorpe, Lukes, Bever, \& He, 2016). A study at a small Catholic university, used library user surveys to investigate the library's impact on GPA, retention, and degree completion (Stemmer \& Mahan, 2016). The findings revealed that although students engage with the library differently at different points in their college career, moving between valuing library for its services, resources and physical space, for all years there is a positive association between library use and GPA and retention (Stemmer \& Mahan, 2016).

Among studies looking at single variables in library use and their impact on academic attainment, studies exploring the use of online resources and library instruction are most common. Student use of online resources and cumulative GPA are positively correlated for all cohorts (Cherry, Rollins, \& Evans 2013). LeMaistre, Shi, \& Thanki (2018) found the same pattern when they looked at online resources use and one-semester GPA and retention across all years. 
Gaha and Pellegrino (2018) found a correlation between attending library instruction and higher cumulative GPA, while O'Kelly (2015) reported four years in a row on a positive statistically significant impact of library instruction on retention.

It should be pointed out that the above studies do not demonstrate a causal relationship between library use and students' outcomes, and, as Allison (2015) puts it, "it is difficult to say whether library use makes good students, or library use is a characteristic of a good student" (p. 37). What emerges from research, however, is that the library, its services and resources, are integral to the institutional mission of offering support services that promote student success.

\section{Academic Libraries and Latinos}

In light of the documented positive relationship between libraries and student success, it is crucial that academic libraries strive to support students in ways that most effectively help them meet their educational goals. Just like HSIs in general have been investigating and employing institutional strategies that target Latino students, academic librarians at HSIs and beyond have started looking more specifically at the role libraries play in Latino students' lives. Whitmire (2003) emphasizes librarians' responsibility to learn about and understand how diverse students experience the library in order to "provide better services that assist undergraduates with their academic integration and subsequent retention and academic achievement" (pp. 148-149). Writing about Latino students specifically, Haras, Lopez, \& Ferry (2008) see "serious implications for the education of Latinos and their retention rates when considering both their use of the library and their research skills, since information literacy 
informs writing, a core academic literacy" (p. 425). In turn, Long (2011) pointedly argues that academic library's demonstrated positive effect on retention (and other educational outcomes) on the one hand and the high rate of Latino attrition on the other hand warrant an investigation of the practical factors that negatively impact their library use.

The removal of barriers to access and use is not the only reason why librarians should explore how culture shapes the ways Hispanic students perceive and use the library. As Jaeger, Bertot, and Franklin (2010) pointedly observe, librarians' “professional commitment to serving diverse patron communities ... has never translated into librarianship becoming a truly diverse profession" (175). According to the 2017 ALA Demographic Study Report 86.7\% librarians identify as White, $4.7 \%$ as Hispanic or Latino, $4.4 \%$ as African American, and $3.6 \%$ as Asian American (Rosa \& Henke, 2017). Given the lack of diversity among librarians, libraries predominantly reflect and operate on White cultural values (Adkins \& Hussey, 2006; Long, 2011). Rather than expecting diverse users to adopt existing norms, libraries must strive to "mak[e] diversity integral and structural" (Dali \& Caidi, 2017, p. 89). Organizational change must start with acknowledging and allowing "the influx of a different cultural, linguistic, social, and religious capital" that diverse groups bring with them (Dali \& Caidi, 2017, p. 95).

Only if librarians learn about and understand what Latino students need and benefit from the most, can academic libraries modify their modus operandi to better serve this growing group of student population. It is important to recognize that adapting library services with the aim of increasing persistence and retention among Latino students does not come at the cost of non-Latino students. As Santiago and Andrade (2010) point out, focusing on the unique needs of Hispanic students "does not mean that institutions serve Latinos at the expense of 
other students. A Latino student success model is not an either/or proposition. Rather, institutions that serve their students well can build on what works in serving Latino students effectively to better serve other students as well” (p. 8). In other words, what is most effective in fostering Latino students' outcomes can be applied to and benefit students from all backgrounds. It is with this understanding that the literature review on Latinos and academic libraries is organized around four major themes: Hispanic students and library attitudes and use; Hispanic students and information literacy; pedagogical strategies for teaching Latino students, and recommendations for practice. While the above categories are not exhaustive, insights from research in these key four areas can be readily applied in practice. I offer the case of the Lloyd Sealy Library at John Jay College of Criminal Justice, at the City University of New York, an HSI, as an illustrative example of what such incremental "work-in-progress" shift towards modifying services to better match the needs of Latino students may look like.

\section{Library Attitudes and Use among Hispanic Students}

A few common themes emerge from studies exploring how Latino students perceive and use the library. Researchers have found that culture plays an important role in how Latinos navigate libraries and their resources, including interactions with reference librarians. Another recurring observation is the contrast between students' familiarity with public libraries and the contrasting confusion about the role of the academic library in their educational pursuits. The importance of library space as a learning environment for Hispanic students has also been repeatedly shown. Similarly, research has demonstrated the positive impact library instruction has on Latino students' academic achievement. Reports of successful faculty-librarian 
collaborations and development of information literacy courses or program-integrated curricula offer models for consideration.

\section{Role of Culture}

In her pioneering study, Whitmire (2003) compared academic library use of Asian American, African American, Latino, Native American and White undergraduates in order to explore if different cultural groups use the library differently. Library use included accessing journal articles, using the catalog, checking out books, asking a librarian for help, and using the library as a place to read or study, among other activities (Whitmire 2003). Conducting a secondary analysis of the 1996 College Student Experiences Questionnaire (CSEQ), Whitmire (2003) found that even as the overall library use rates were comparable, students of color, including Latinos, used the library to a greater extent than whites did. Factors associated with higher library use differed for each group; for Hispanic students they were linked with course learning activities, writing experiences, the number of non-assigned (leisure) books read, and class year (Whitmire 2003). Given the findings, Whitmire (2003) suggested that libraries eager to promote the library use among Latinos expand their leisure collections and establish collaborations with classroom faculty who influence how often students use the library.

Adkins and Hussey (2006) also looked at how cultural identity mediates library use. Guided by the question of "who is well served by libraries and who is left behind" (Adkins \& Hussey, 2006, p. 457), they conducted semi-structured interviews with seven Latino college students recruited through the school's Latino Student Services mailing list. Three main questions framed the conversations: do Latinos find academic libraries alienating? What do they think about libraries and librarians? Does the library play a cultural role in the lives of 
Latino students? (Adkins \& Hussey, 2006). Students who were confident in their ability to navigate the library highly rated staff and resources; in contrast, those who felt ill at ease expressed reservations about what the library had on offer (Adkins and Hussey, 2006). For Latino students and others from nondominant groups, "knowing how to use the library is not merely about finding information but also about navigating culture," as libraries reflect norms they may not be familiar with (Adkins \& Hussey, 2006, p. 473). Adkins and Hussey (2006) found that library orientations and instruction sessions increase the comfort level of Latino students; they also suggest that communicating and publicizing library services may be effective in easing students' discomfort further, as is including Latino students in formulating library rules of conduct.

Haras, Lopez, \& Ferry (2008) looked at library use among 105 first-year 1.5 generation Latino students at The California State University, Los Angeles. Generation 1.5 students, the researchers explain, "are neither international students nor do they see themselves as ESL learners. They are somewhere between first-generation, adult immigrants who are foreign-educated and U.S.-born English-dominant speakers" (Haras, Lopez, \& Ferry, 2008, p. 426). Focus groups and an online survey revealed that few students had prior knowledge of the library and its resources and their relevance to studying, possibly because most public schools in the state lacked a library; about a quarter of students did not have to write a research paper prior to college (Haras, Lopez, \& Ferry, 2008). Echoing Adkins and Hussey's (2006) recommendation, Haras, Lopez, \& Ferry (2008) see library instruction in the first year appears is key to introducing and promoting library use among Latino students, especially that a great 
majority of students valued the library and half saw it as supportive in their schoolwork, rating it higher rated than the writing center and tutoring services.

Dabbour and Ballard (2011) conducted a randomized self-administered survey to White and Latino students at a large public university. Overall, the results corroborated Whitmire's (2003) findings as Dabbour and Ballard (2011) also found that the two groups use library differently and at different rates. Latinos not only spent more time in the library than white students did, but they also relied on the library for internet access, email and course-related software more often than white students did (Dabbour \& Ballard, 2011). A related finding indicated that off-campus library use was higher among white students, suggesting that Latinos have lower rate of home internet access (Dabbour \& Ballard, 2011).

Long (2011) interviewed nine undergraduate self-identified Latino students (sophomore through junior) enrolled at the Illinois State University. He found that Latinos were keenly aware that the academic library reflects "white or Caucasian cultural values and systems more than Latino cultural values and systems" (p. 505). The interviewees critically commented on the lack of Spanish-language leisure periodicals, materials, and signage; they also took note of the lack of Latino representation in the library visuals such as posters and pictures (Long, 2011). Hiring diverse staff, as well as ensuring appropriate targeted publicity and programming, should become a priority for academic libraries aiming to become a valuable resource for Hispanic students (Long, 2011).

Green (2012) conducted an analysis of self-identified Latino student data gathered in the course of the Ethnographic Research in Illinois Academic Libraries (ERIAL) Project that aimed collect information on student library use to improve services at the five participating 
libraries. The findings corroborated previous research on Hispanic students' relationships with libraries, including their lack of clarity about academic library's role.

\section{Public Library vs. Academic Library}

The contrast between the familiarity with public libraries and confusion about the role of academic libraries is another recurring theme in the literature about Latino students' library use. Haras, Lopez, \& Ferry (2008) established that Latino students who had pre-college experience with school library showed higher levels of information literacy and research skills, but they cautioned that few students had such prior knowledge as school libraries are rarely available. In turn, students' familiarity with public libraries did not readily translate into their ability to relate academic library and its resources to coursework (Haras, Lopez, \& Ferry, 2008). This finding corroborated Adkins and Hussey's (2006) assertion that for Latino students who used both academic and public libraries, each served a different purpose: while the former were used for coursework, the latter offered cultural support. And yet, while Latino students understand the role of the public library well, they are less clear about how to use the academic library for their academic advantage (Green 2012; Long 2011; Lumley, Newman, \& Brown, 2015). All in all, the reported comfort with public libraries does not extend to Latino students' experience with the academic library.

The lack of clarity about the academic library's purpose undoubtedly contributes to low rate of direct interactions between Latino students and librarians (Green 2012; Long 2011; Lumley, Newman, \& Brown, 2015; Montiel-Overall, Nuñez, \& Reyes-Escudero, 2015). The other identified factor that is negatively affecting Hispanic students' use of reference services is related to their cultural preference to seek assistance and information from already trusted 
sources and individuals (Morrison 2009; Nuñez 2013). Green (2012) found not having personal connections to academic librarians, Latino students were reluctant to ask for help or assistance, consulting instead those they knew better, such as their instructors, high school teachers, familiar public librarians, or peers. Clink (2016) reported that those who had no prior contact with librarians felt uncomfortable asking for help or asking questions because they feared it would expose their lack of knowledge about the library and its resources.

In light of the above findings, academic libraries should strive towards increasing Hispanic students' familiarity and ease with their resources, including the availability of reference assistance. It bears pointing out that Latino students who interact with library staff do report positive experiences (Adkins and Hussey, 2006; Clink 2016; Haras, Lopez \& Ferry 2008). While most students first encounter a librarian at orientation, first-year library instruction sessions or workshops, it is important that librarians continue to expand their reach beyond these contexts.

\section{Academic Library as Space}

In addition to the mediating impact of culture and the lack of clarity about academic library's role, the importance of library as physical space has been well recognized in studies about Latinos students' library use. Hispanic students predominantly value the campus library as a study space, whether to study alone (quietly and with no distractions) or in a group (Adkins and Hussey 2006; Clink 2016; Green 2012; Haras, Lopez \& Ferry, 2008; Long 2011). Other popular uses of library space include formal and informal mentoring (Green 2012); socializing was reported at a much lower rate (Adkins \& Hussey, 2006). The most frequently used course-related library services include reserves and book borrowing (Adkins \& Hussey, 2006; 
Clink 2016; Haras, Haras, Lopez, \& Ferry 2008.). Highly-valued, library-provided access to computer workstations allows students to search databases, write and read emails, and do homework (Adkins and Hussey 2006; Clink 2016; Haras, Lopez \& Ferry 2008; Green 2012). Computers in libraries are crucial as Latinos own computers at lower rate than other racial and ethnic groups (Dabbour and Ballard, 2011; Lumley, Newman, \& Brown, 2015). Interestingly, even as Latino students heavily rely on library computers, they distinguish between the library and campus computer labs, appreciating the library's unique atmosphere conducive to studying (Adkins and Hussey 2006; Clink 2016). Just as the knowledge about library increases Latino students' comfort with services and staff does, the ability to navigate library space translates into their confidence in using the library. Adkins and Hussey (2006) discovered that for Hispanic students library size matters: the larger the library is, the more complex and the less personal it gets, affecting how students perceive and interact with it.

The findings about how Latino students use the library space underscore the critical role libraries play in providing a learning environment. They also offer insights into how libraries can modify their spaces--by designating individual or group study areas, creating a social space, or adding computers, for example--to accommodate Latino students' needs and preferences.

\section{Information Literacy, Library Instruction and Latino Students}

The documented disparity between white and Latino students' pre-college educational experiences means that the latter enter college underprepared for the academic rigor ahead (Nora \& Crisp, 2009). Given that many Hispanic students have not worked on research projects prior to college, learning to do research is among the crucial skills first-year Latino students need to master (Haras, Lopez and Ferry, 2008; Montiel-Overall, Nuñez, \& Reyes-Escudero, 
2015). Effective library instruction, then, is key to promoting Latino students' academic achievement.

Understanding how Latino students find, access and process information, Morrison (2009) suggests, may help librarians identify ways in which information literacy instruction may be modified to align more closely with their habits. Although culturally-relevant pedagogy has been adopted in other areas of education, Morrison (2009) points out, that it remains "a neglected issue in librarianship" (p. 31). To address the omission, he looked at how self-identified Latino students' cultural background mediated their information seeking behavior. Prior to entering college, Morrison (2009) found, students relied on and trusted information gathered from their social and familial networks, including public libraries. Once in college, they extended their trust to instructors and librarians with whom they interacted. Latino students' background, Morrison (2009) concludes, was both a factor and an asset in their ability to locate, evaluate and use information. Latino students built on their culture's emphasis and valuation of education; they also extended their habits of consulting authoritative community members and resources to include college faculty and the library (Morrison 2009). Morrison's (2009) call to adapt modes of library instruction to better serve Latino students was echoed by Dabbour and Ballard (2011). Although in their survey both White and Latino students alike agreed that information literacy skills are crucial to their academic work, Latino students--who had received more information literacy instruction than white students-scored lower on the information literacy tests administered as part of the study (Dabbour \& Ballard, 2011). The score discrepancy, Dabbour and Ballard (2011) concluded, indicated an urgent need to modify pedagogical approaches to teaching information literacy skills to Latinos. 
Intent on identifying and describing the most effective ways of working with Latino students, the literature on pedagogical approaches to library instruction includes case studies of one-shot instruction, semester-long information literacy courses and faculty-librarian collaborations.

At the University of Arizona, Walsh (2013) investigated how the use of targeted connectivism-based and culturally responsive information literacy instruction may promote an increase in library use and information literacy skills among first-year Latino students. He found that compared with students who received no library instruction at all, students who had either targeted or traditional information literacy instruction subsequently used library at a higher rate and improved their information literacy skills. While Walsh (2013) did not observe significant differences between the methods of instruction, he suggests that targeted culturally responsive pedagogy in library classes presents a viable alternative to traditional approaches. Since information literacy instruction and library use both have positive demonstrable outcomes, Walsh's (2013) study underscores the importance of reaching Latino students and providing them with library instruction.

Mestre (2004) developed a bilingual information literacy course for Latinos at the University of Massachusetts Amherst. The course on "Essentials of Library Research" was coordinated through the Bilingual Collegiate Program (BCP), a support program on campus. Over the two years it was offered, the course had been repeatedly modified to better reflect the students' cultural and linguistic background. The instructor used Latino online newspaper headlines as discussion and research prompts, and emphasized students' prior experiences, interests and questions when conducting classes. To foster a deeper relationship with students, 
Mestre (2004) shared personal stories, encouraged email communication, and offered frequent individual feedback. These pedagogical strategies conveyed the librarian's investment in the course and resulted in higher student attendance and participation. In follow-up interviews, Mestre (2004) found that the rapport and caring instructor were key to student satisfaction and persistence.

Delgado and Luévano (2007) describe a successful collaboration between a librarian and Chicano and Latino Studies Department faculty at the California State University, Long Beach. The collaboration was part of a grant-funded project addressing curriculum-integrated information literacy skills in the department. A multiyear collaboration between librarian and teaching faculty member evolved into a department-level curriculum, integrating library skills into four core courses in the Chicano and Latino Studies major and minor. Delgado and Luévano's (2007) long-term collaboration resulted in programmatic curriculum integration; it may serve as a model for librarians determined to reach out and work directly with departments enrolling large groups of Hispanic students. Targeted and focused, such a joint effort has seamlessly infused information literacy into the curriculum, scaffolding students information literacy skills throughout the course sequence.

Hein and Miller (2004) report on their collaboration that, although smaller in scale than Delgado and Luévano's (2007), has also managed to embed information literacy into multiple courses taught by the Chicana and Chicano Studies Department the California State University, Fullerton. Hein and Miller (2004) worked together to develop an assignment that asked students to place their own family history in a historical context. The course on the Chicano family required students to explore their ancestors' past in the larger historical context 
affecting the community. In addition to co-designing the specific assignment and being available for individual consultations, the librarian provided library instruction a few times throughout the course. The library and research workshops were scheduled to coincide with specific points in the research process. The assignment and collaboration were so effective that the instructor-librarian pair adapted it to fit other courses taught by the faculty.

In addition to integrating information literacy into the curriculum at the program or course level, the above successful collaborations model additional strategies that have been described in the Latino student success literature. The students are able to get to know the teaching librarian well; they are also able to obtain individual assistance from someone they already have a relationship with. In addition, the library and its resources are demonstrated to provide access to culturally relevant information. All of these factors are likely to result in Latino students' greater comfort with the library, which may then translate into greater use.

\section{Recommendations for Practice}

As Latino college enrollment is projected to continue to grow in the coming decades, academic libraries at HSIs and beyond will be serving increasing large numbers of Hispanic students. Developing cultural competence, that is learning and understanding how cultural background shapes ways in which Latinos use the library, "is essential for LIS professionals who work with and provide services to these groups" (Montiel-Overall, Nuñez, \& Reyes-Escudero, 2015, p. 2). As academic libraries rethink services and resources to better serve Hispanic students, the changes ought to be guided by what has been documented to work best for them. Solis and Dabbour (2006) report on the U.S. Department of Education's Title V grant 
awarded to the Oviatt Library at the California State University Northridge. The project sought to improve students' academic success by encouraging library use among Latinos. The funds were used to build up Latino-related collections, including archives, expand the instruction program, intensify outreach, and hire additional staff (Solis and Dabbour, 2006). There is no doubt that additional funding, such as Title $V$ grants, is sorely needed to adapt and expand services that would adequately meet the needs of Latinos. In reality, however, most colleges and universities--and academic libraries by extension--will have to do so in the context of "limited institutional resources to improve or expand institutional practices" (Santiago \& Andrade, 2010, p. 4). Accordingly, the following list of selected best practices emphasizes those strategies that can be implemented with minimal or no additional funding. In no way exhaustive, these recommendations for practice draw from the literature reviewed above.

\section{Developing Cultural Competence}

In order to implement changes that would effectively improve the library experience for Latino students, it is crucial to start by acknowledging that longtime services do not adequately meet their needs. Learning about Hispanics as a group with specific characteristics will aid in identifying what needs to be changed and how to go about it. In order to get a sense of Latino students at his institution as a group, Green (2012) analyzed previously collected data to focus on Latino students specifically and requested additional information from the office of institutional research. These locally gathered ethnographic insights led to an actionable plan the library later implemented. Among the resulting changes was the addition of Hispanic-focused materials, hiring more Latino student assistants and Spanish-speaking librarians, and collaborating more closely with peer counselors. Montiel-Overall, Nuñez, \& 
Reyes-Escudero (2015) advocate an asset-based approach to working with Latino students, a model in which Latino background is not seen as an obstacle to students' educational success. Focusing on and highlighting the positive contributions Latinos make to the college community will promote "knowledge and respect of cultural diversity and the recognition that differences are the basis for creative and innovative thinking" (Montiel-Overall, Nuñez, \& Reyes-Escudero, 2015, p. xi). To foster cultural competence among LIS professionals, they share interviews with Latino librarians whose experiences illustrate the nuances of navigating the academic library as student and staff (Montiel-Overall, Nuñez, \& Reyes-Escudero, 2015). Molteni and Bosch (2014), in turn, emphasize that learning about how Latinos' cultural background modulates their library use is not enough; in order for the service model to shift, cultural competence workshops need to be offered to all library staff members.

\section{Personalizing Services}

As the Latino community highly values close trusted relationships, personalizing services appears as an effective way to attract Hispanic students to the library (Kiyama, Museus, \& Vega, Montiel-Overall, Nuñez, \& Reyes-Escudero 2015; Nuñez, 2013). As discussed above, for a majority of Latino students the role of librarians is unclear, and they remain strangers who are rarely asked for assistance. Green (2012), Montiel-Overall, Nuñez, \& Reyes-Escudero (2015), and Molteni, V. E., \& Bosch, E. K. (2014) all suggest that libraries should personalize their services. While personalization will look different in different libraries, some possibilities include adding photographs and brief biographical notes on librarians' webpages (Montiel-Overall, Nuñez, \& Reyes-Escudero, 2015). Extending librarians' presence in non-library campus locations popular with students has also been suggested (Green, 2012), as has 
relocating or rearranging reference desk to allow for more intimate interactions (Green, 2012;

Montiel-Overall, Nuñez, \& Reyes-Escudero). Targeted outreach to student groups and peer-mentors is yet another initiative that has been put in action (Green, 2012; Montiel-Overall, Nuñez, \& Reyes-Escudero, 2015). Libraries who employ Spanish-speaking staff have also reported offering bilingual reference consultations and instruction so that students with limited English proficiency can fully benefit from both (Molteni \& Bosch, 2014).

\section{Teaching Information Literacy}

Presented in a variety of formats, information literacy instruction, is another initiative libraries should actively pursue to improve Latino students' academic experience. Given Latino students' unfamiliarity with the function of academic library, orientations, workshops, and course-integrated instruction should ideally be offered early in the first year (Long, 2011; Green, 2012). To engage students more directly, Montiel-Overall, Nuñez and Reyes-Escudero (2015) urge librarians to seek out opportunities to teach alongside classroom faculty more often. Green (2012) recommends information literacy instruction beyond the library and the classroom; partnering up and training peer mentors is just one strategy worth trying. Molteni and Bosch (2014) suggest that, if possible, libraries develop multilingual learning objects to complement instruction and reference services, including online tutorials, research guides, or supplementary websites.

\section{Removing Barriers to Library Use}

More or less directly, the above recommendations aim to promote library use among Latinos by addressing factors that prevent students from taking advantage of services offered, including limited prior experience with academic library and research, lack of clarity about 
academic library's purpose, and no established relationships with library staff. To draw Hispanic students to the library, libraries must also take steps to reduce the complexity and increase the convenience of available services (Green, 2012; Molteni \& Bosch, 2014). Getting feedback from students and alumni--through surveys or focus groups-- can help identify specific obstacles and barriers that negatively impact the use of library services (Green, 2012; Montiel-Overall, Nuñez, \& Reyes-Escudero, 2015). Green (2012) lists changes that resulted from conducting a local study of Hispanic students' needs: the library adjusted hours and added a satellite service desk in another campus location; photocopying services were improved and additional computers were added. For libraries that lack resources, simplifying rather than expanding services may be the more feasible, yet also effective, way to address barriers to service. For example, re-examining and reducing the steps needed to borrow a book, sign up onto a library computer, access an online article, or reserve a study room may result in better experience for students.

\section{Adapting Recommendations for Practice: The Lloyd Sealy Library}

This section offers the example of The Lloyd Sealy Library at John Jay College of Criminal Justice, the City University of New York, to illustrate strategies an academic library at an HSI may undertake to better serve Latino students. A senior college within the City University of New York (CUNY), John Jay College of Criminal Justice was established in 1964. It enrolls 13,000 undergraduates and 2,000 graduate students, $47 \%$ of them Latino; overall $47 \%$ of John Jay students are the first in their families to attend college (John Jay College, n.d., Fast...). A Hispanic Serving Institution and Minority Serving Institution, John Jay College boasts the largest Hispanic student population of any four-year college in the Northeast (John Jay College, n.d., Facts...). It is also ranked among the top five multicultural and inclusive colleges in New York 
City by the Wall Street Journal/Times Higher Education (THE) College Rankings (John Jay College, n.d., A Premier...). The Lloyd Sealy Library has continually striven to meet students' shifting needs. Throughout the years, the Library has relied on a variety of student feedback, including periodic in-library use and related surveys, website usability studies, as well as informal feedback gathered during classes and reference interactions. In addition, John Jay librarians have always been encouraged to take advantage of the many professional development activities, many of which focus on student services, available at CUNY and beyond. As a result, the Library has a strong record of well informed and strategic service adaptations aimed at improving the library experience for students. The recent initiatives described below illustrate how the Library adapted some of the best practices for working with Hispanic students to fit the local context.

To develop cultural competence and learn about Latino students, librarians have been attending campus-wide events and lectures, including the HSI Speaker Series sponsored by the Office of the Provost. The lectures provoked discussions and reflections on the ways the Library does and does not serve Latino students well. Such conversations, Montiel-Overall, Nuñez, and Reyes-Escudero (2015) write are key in moving a library towards embracing diversity. The Library also featured Latino related resources in one of the departmental newsletters distributed on campus, Latino studies was added to Databases by Subject list on the Library website, and a librarian presented a workshop on Latino and Diversity collections at a Faculty Development Day.

As most libraries, ours lacks staff resources, and personalizing services remains a challenge. However, there are steps some librarians have taken to establish better rapport with 
students. Wearing name tags, introducing oneself at the start of a reference interaction, and sharing contact information with students have proven effective in establishing lasting relationships with students who return for assistance after the initial contact. Another initiative involved stabilizing reference desk shifts so that individual librarians were scheduled at the same time and the same day of the week for a month or longer. Given librarians' many responsibilities, it was unfeasible to maintain such a rigid schedule, however, for long. The regular shifts were intended to enable students who follow a class schedule to meet the same librarian on the days they are on campus. Indeed, students appreciated knowing when a particular librarian will be at the desk again. Some librarians have also taken advantage of a Student Engagement grant founded by the College to offer "Lunch with a Librarian" to winners of Escape the Library challenge, a team-based game familiarizing students with basic library services and resources, that is offered in collaboration with the First Year Experience Program. The celebratory meal allowed for an informal interaction with a librarian, outside of the library setting.

When it comes to information literacy instruction, the Library emphasizes working with first-year students, in line with what the literature on Hispanic students' recommends. The multiple formats of instruction the Library offers include Escape the Library challenge, offered over the summer or early in the fall, drop-in workshops designated as First Year Friendly, class visits for First Year Seminars, and formal sessions for ENG 101, the first course in the composition series. Teaching librarians often encourage students to follow up with them after a workshop or class to schedule a personal consultation, if needed. While librarians work on being more readily available to students, they also actively reach out to faculty. The instruction 
coordinator presents at professional development training days for ENG 101 instructors; in addition, librarians are regular presenters at the College's Faculty Development Day each semester.

The Lloyd Sealy Library has also been committed to minimizing barriers to Latino students' library use, recognizing that all improvements will benefit the entire student population. As some of the changes have required financial expenditures not accounted for in the annual budget, the Library has been actively pursuing funding from other sources on campus. In response to students' request, the Library now offers $24 / 7$ library lab access before and during finals. The money to sponsor the initiative comes from the Student Government. The Library has also repeatedly applied for and used Tech Fee funding to pay for equipment that allowed for expansion of services. Book scanners, additional outlets and chargers, group study rooms and equipment are among the additions made possible by the extra funding. In collaboration with the College IT department, the Library was able to add a Print Anytime station just outside of the entrance. Students are able to print out papers even when the Library is closed. To minimize the cost of textbooks for students, the Library actively participates in the CUNY OER initiative; the College grant included hiring a part-time librarian who works with faculty directly.

\section{Conclusion}

The above examples of service modifications and additions at the Lloyd Sealy Library follow recommendations for practice that emerge from the literature on Latino students and academic libraries. There are, undoubtedly, many other initiatives that may and should be undertaken in the future. Incremental as they may be, the steps the Library has taken towards 
becoming a trusted and reliable resource have already aligned it more closely with the educational needs of Hispanic students. As the Latino college enrollment continues to grow in coming years, academic libraries must make a concerted effort to re-examine and modify their service models to work more effectively with this expanding group. By reviewing relevant literature and providing examples of applications for practice, this article aimed to encourage libraries to undertake this transition. 


\section{REFERENCES}

Adkins, D., \& Hussey, L. (2006). The library in the lives of Latino college students. The Library Quarterly, 76(4), 456-480.

Allison, D. (2015). Measuring the academic impact of libraries. Portal: Libraries and the Academy, 15(1), 29-40.

Beile, P., Choudhury, K., \& Wang, M. C. (2017). Hidden treasure on the road to Xanadu: what connecting library service usage data to unique student IDs can reveal. Journal of Library Administration, 57(2), 151-173.

Cherry, E., Rollins, S. H., \& Evans, T. (2013). Proving our worth: The impact of electronic resource usage on academic achievement. College \& Undergraduate Libraries, 20(3-4), 386-398.

Clink, K. (2016). Libraries and Hispanic students: A study. (Unpublished paper, Minnesota State University, Mankato, MN). Retrieved from https://cornerstone.lib.mnsu.edu/lib_services_fac_pubs/141/

Dabbour, K. S., \& Ballard, J. D. (2011). Information literacy and U.S. Latino college students: a cross-cultural analysis. New Library World, 112(7/8), 347-364.

Dali, K., \& Caidi, N. (2017). Diversity by design. The Library Quarterly, 87(2), 88-98.

Delgado, G.P., \& Luévano, S.C. (2007), “Semillas de Cambio: the teaching of information competency in Chicano and Latino studies", in Jacobson, T.E. and Mackey, T.P. (Eds), Information literacy collaborations that work, Neal-Schuman Publishers, New York, NY, pp. 95-108.

Excelencia in Education. (2014). HSI origin timeline. Retrieved on October 19, 2018 from 
https://www.edexcelencia.org/research/infographics/hsi-origin-timeline

Flores, A. (2017). Facts on U.S. Latinos, 2015: Statistical portrait of Hispanics in the United States. Retrieved on October 15, 2018 from http://www.pewhispanic.org/2017/09/18/facts-on-u-s-latinos/

Flores, A., Lopez, G., \& Radford, J. (2017). Facts on U.S.Latinos, 2015: Statistical portrait of Hispanics in the United States. Retrieved on October 15, 2018 from http://www.pewhispanic.org/2017/09/18/facts-on-u-s-latinos-trend-data/

Gaha, U., Hinnefeld, S., \& Pellegrino, C. (2018). The academic library's contribution to student success: Library instruction and GPA. College \& Research Libraries, 79(6), 737-746.

Green, D. (2012). Supporting the academic success of Hispanic students. In L. M. Duke \& A.D. Asher (Eds.), College libraries and student culture: What we now know (pp. 87-108). Chicago, IL: American Library Association.

Haras, C., Lopez, E. M., \& Ferry, K. (2008). (Generation 1.5) Latino students and the library: A case study. The Journal of Academic Librarianship, 34(5), 425-433.

Hein, N. P., \& Miller, B. A. (2004). ¿Quién Soy? Finding my place in history: Personalizing learning through faculty/librarian collaboration. Journal of Hispanic Higher Education, 3(4), 307-321.

Hispanic Association of Colleges \& Universities (HACU). (n.d). HACU list of Hispanic-Serving Institutions (HSIs) 2016-17. Retrieved on October 19, 20018 from https://www.hacu.net/hacu/HSIs.asp 
Humes, K., Jones, N.A., \& Ramirez, R. R. (2011). Overview of race and Hispanic origin: 2010.

Retrieved on October 15, 2018 from

https://www.census.gov/prod/cen2010/briefs/c2010br-02.pdf

Jaeger, P. T., Bertot, J. C., \& Franklin, R. E. (2010). Diversity, inclusion, and underrepresented populations in LIS research. The Library Quarterly, 80(2), 175-181.

John Jay College of Criminal Justice. (n.d.). A premier Hispanic and Minority Serving Institution. Retrieved on October 22, 2018 from http://www.jjay.cuny.edu/premier-hispanic-and-minority-serving-institution John Jay College of Criminal Justice. (n.d.). Fast facts. Retrieved on October 22, 2018 from http://www.jjay.cuny.edu/fast-facts

John Jay College of Criminal Justice. (n.d.). Facts \& resources. Retrieved on October 22, 2018 from http://www.jjay.cuny.edu/diversity-facts-resources

Kiyama, J. M., Museus, S. D., \& Vega, B. E. (2015). Cultivating campus environments to maximize success among Latino and Latina college students. New Directions for Higher Education, 2015(172), 29-38.

LeMaistre, T., Shi, Q., \& Thanki, S. (2018). Connecting library use to student success. Portal: Libraries and the Academy, 18(1), 117-140.

Long, D. (2011). Latino students' perceptions of the academic library. The Journal of Academic Librarianship, 37(6), 504-511.

Lumley, R., Newman, E., \& Brown, H. T. (2015). Hispanic college students' library experience. Contemporary Issues in Education Research, 8(1), 49-54. 
Maestas, R., Vaquera, G. S., \& Zehr, L. M. (2007). Factors impacting sense of belonging at a Hispanic-serving institution. Journal of Hispanic Higher Education, 6(3), 237-256.

Mestre, L. S. (2004). Culturally relevant instruction for Latinos. Academic Exchange Quarterly, $8(1), 46-51$.

Merisotis, J. P., \& McCarthy, K. (2005). Retention and student success at minority-serving institutions. New Directions for Institutional Research, 125, 45-58.

Molteni, V. E., \& Bosch, E. K. (2014). Reference services in a shifting world: Other languages, other Services. In C. Forbes \& J. Bowers (Eds.), Rethinking reference for academic Libraries: Innovative developments and future trends (pp. 51-67). Lanham, MD: Rowman \& Littlefield.

Montiel-Overall, P., Nuñez, A. V., \& Reyes-Escudero, V. (2015). Latinos in libraries, museums, and archives: Cultural competence in action! An asset-based approach. Lanham, MD: Rowman \& Littlefield.

Morrison, R. (2009). Culturally-relevant information literacy: A case study. (Doctoral thesis, National Louis University, Chicago, IL). Retrieved from https://digitalcommons.nl.edu/diss/20/

Murray, A. (2015). Academic libraries and high-impact practices for student retention: Library deans' perspectives. Portal: Libraries and the Academy, 15(3), 471-487.

National Center for Education Statistics. (2016). Digest of education statistics. Retrieved on October 17, 2018 from https://nces.ed.gov/programs/digest/d16/tables/dt16_326.10.asp 
National Center for Education Statistics. (n.d.). Fast facts. Retrieved on October 15, 2018 from https://nces.ed.gov/fastfacts/display.asp?id=98

Nora A., \& Crisp, G. (2009) Hispanics and higher education: An overview of research, theory, and practice. In J.C. Smart (Ed.), Higher education: Handbook of theory and research (pp. 317-353). Dordecht, Germany: Springer.

Nuñez, A. (2013). Latinos in higher education: Creating conditions for student success. Retrieved from https://ebookcentral.proquest.com

O'Kelly, M. (2015). Correlation between library instruction and student retention.

Oliveira, S. M. (2017). The academic library's role in student retention: a review of the literature. Library Review, 66(4/5), 310-329.

Patten, E. (2016). The nation's Latino population is defined by its youth. Retrieved on October 16, 2018 from http://www.pewhispanic.org/2016/04/20/the-nations-latino-population-is-defined-by-it s-youth/

Pew Research Center. (n.d.). About three-quarters of Hispanic Millennials are proficient in English. Retrieved on November 30, 2018 from http://www.pewhispanic.org/2016/04/20/the-nations-latino-population-is-defined-by-it s-youth/ph_2016-04-20_latinoyouth-07

Pew Research Center. (n.d.). Nearly six-in-ten Hispanics are Millennials or younger. Retrieved on November 30, 2018 from http://www.pewhispanic.org/2016/04/20/the-nations-latino-population-is-defined-by-it s-youth/ph_2016-04-20_latinoyouth-01/ 
Rosa, K., \& Henke, K. (2017). 2017 ALA demographic study. Retrieved on October 22, 2018 from http://www.ala.org/tools/sites/ala.org.tools/files/content/Draft\%20of\%20Member\%20 Demographics\%20Survey\%2001-11-2017.pdf

Santiago, Deborah A., \& Andrade, S. J. (2010). Emerging Hispanic-Serving Institutions (HSIs): Serving Latino students. Retrieved on October 16, 2018 from https://files.eric.ed.gov/fulltext/ED508202.pdf

Solis, J., \& Dabbour, K. S. (2006). Latino students and libraries: a U.S. federal grant project report. New Library World, 107(1/2), 48-56.

Soria, K. M., Fransen, J., \& Nackerud, S. (2013). Library use and undergraduate student outcomes: New evidence for students' retention and academic success. Portal: Libraries and the Academy, 13(2), 147-164.

Soria, K. M., Fransen, J., \& Nackerud, S. (2017). Beyond books: The extended academic benefits of library use for first-year college students. College \& Research Libraries, 78(1).

Stemmer, J. K., \& Mahan, D. M. (2016). Investigating the relationship of library usage to student outcomes. College \& Research Libraries, 77(3), 359-375.

Stone, G. (2015). Library impact data: investigating library use and student attainment. In: Library analytics and metrics: Using data to drive decision and services. Facet, London, pp. 51-58.

Stone, G., Pattern, D., \& Ramsden, B. (2011). Does library use affect student attainment? A preliminary report on the Library Impact Data Project. Liber Quarterly, 21(1). 
Thorpe, A., Lukes, R., Bever, D. J., \& He, Y. (2016). The impact of the academic library on student success: Connecting the dots. Portal: Libraries and the Academy, 16(2), 373-392.

United States Census Bureau. (2017). Selected population profile in the United States: 2017 American Community Survey 1-year Estimates. Retrieved on October 15, 2018 from https://factfinder.census.gov/faces/tableservices/jsf/pages/productview.xhtml?ssc=bk $\mathrm{mk \#}$

U.S. Department of Education. (2016). Definition of Hispanic Serving Institutions. Retrieved on October 19, 2018 from https://www2.ed.gov/print/programs/idueshsi/definition.html U.S. Department of Education. (n.d.). Hispanic Serving Institutions (HSIs). Retrieved on October 19, 2018 from https://sites.ed.gov/hispanic-initiative/hispanic-serving-institutions-hsis/ U.S. Department of Education. (n.d.) White House initiative on educational excellence for Hispanics. Retrieved on October 19, 2018 from https://sites.ed.gov/hispanic-initiative/ Walsh, J. B. (2013). The effects of targeted, connectivism-based information literacy instruction on Latino students information literacy skills and library usage behavior (Doctoral dissertation, The University of Arizona, AZ). Retrieved from https://repository.arizona.edu/handle/10150/312502

Whitmire, E. (2003). Cultural diversity and undergraduates' academic library use. The Journal of Academic Librarianship, 29(3), 148-161. 
Table 1

Nearly six-in-ten Hispanics are Millennials or younger

\begin{tabular}{|l|l|l|l|l|l|}
\hline Race/Ethnicity & $\begin{array}{l}\text { Younger } \\
\text { than 18 }\end{array}$ & $\begin{array}{l}\text { Millennial } \\
\text { adults } \\
(18-33)\end{array}$ & Gen X (34-49) & $\begin{array}{l}\text { Boomer } \\
(50-68)\end{array}$ & $\begin{array}{l}\text { Silent/Greate } \\
\text { st (69 and } \\
\text { older) }\end{array}$ \\
\hline Hispanic & $32 \%$ & 26 & 22 & 14 & 4 \\
\hline Black & $26 \%$ & 25 & 21 & 21 & 7 \\
\hline Asian & $20 \%$ & 25 & 25 & 25 & 8 \\
\hline White & $19 \%$ & 20 & 20 & 20 & 13 \\
\hline
\end{tabular}

Source:

Pew Research Center. (n.d.). Nearly six-in-ten Hispanics are Millennials or younger. Retrieved on November 30, 2018 from http://www.pewhispanic.org/2016/04/20/the-nations-latino-population-is-defined-by-it s-youth/ph_2016-04-20_latinoyouth-01/ 
Table 2

About three-quarters of Hispanic Millennials are proficient in English

\% among Hispanics

\begin{tabular}{|l|l|l|l|l|l|}
\hline $\begin{array}{l}\text { English } \\
\text { proficiency } \\
\text { level }\end{array}$ & Ages 5-17 & $\begin{array}{l}\text { Millennial } \\
\text { adults } \\
(18-33)\end{array}$ & Gen X (34-49) & $\begin{array}{l}\text { Boomer } \\
(50-68)\end{array}$ & $\begin{array}{l}\text { Silent/Greate } \\
\text { st (69 and } \\
\text { older) }\end{array}$ \\
\hline $\begin{array}{l}\text { Do not speak } \\
\text { English }\end{array}$ & 1 & 5 & 9 & 12 & 22 \\
\hline $\begin{array}{l}\text { Speak English } \\
\text { less than very } \\
\text { well }\end{array}$ & 12 & 19 & 36 & 37 & 35 \\
\hline $\begin{array}{l}\text { Speak English } \\
\text { very well }\end{array}$ & 50 & 48 & 35 & 32 & 27 \\
\hline $\begin{array}{l}\text { Speak only } \\
\text { English at } \\
\text { home }\end{array}$ & 37 & 28 & 20 & 20 & 16 \\
\hline
\end{tabular}

Source:

Pew Research Center. (n.d.). About three-quarters of Hispanic Millennials are proficient in

English. Retrieved on November 30, 2018 from

http://www.pewhispanic.org/2016/04/20/the-nations-latino-population-is-defined-by-it s-youth/ph 2016-04-20 latinoyouth-07 